\title{
Endovascular Treatment of Ruptured True Posterior Communicating Artery Aneurysms
}

\author{
Rüptüre Gerçek Posterior Komünikan Arter Anevrizmalarnnın \\ Endovasküler Tedavisi
}

\author{
Yonglin $\mathrm{YANG}^{1}$, Wandong $\mathrm{SU}^{2}$, Qinghai $\mathrm{MENG}^{3}$ \\ ${ }^{1}$ The Affiliated Hospital of Qingdao University People's Hospital of Rizhao, Department of Neurosurgery, Qingdao, China \\ ${ }^{2}$ Qilu Hospital of Shandong University, Department of Neurosurgery, Jinan, China \\ ${ }^{3}$ The Affiliated Hospital of Qingdao University, Department of Neurosurgery, Qingdao, China
}

Corresponding Author: Qinghai MENG / E-mail: mengqinghaiqingdao@163.com

\begin{abstract}
AIM: Although true posterior communicating artery ( $\mathrm{PCOA}$ ) aneurysms are rare, they are of vital importance. We reviewed 9 patients with this fatal disease, who were treated with endovascular embolization, and discussed the meaning of endovascular embolization for the treatment of true PCOA aneurysms.

MATERIAL and METHODS: From September 2006 to May 2012, 9 patients with digital substraction angiography (DSA) confirmed true PCoA aneurysms were treated with endovascular embolization. Patients were followed-up with a minimal duration of 17 months and assessed by Glasgow Outcome Scale (GOS) score.

RESULTS: All the patients presented with spontaneous subarachnoid hemorrhage from the ruptured aneurysms. The ratio of males to females was 1:2, and the average age of onset was 59.9 (ranging from 52 to 72 ) years. The preoperative Hunt-Hess grade scores were I to III. All patients had recovered satisfactorily. No permanent neurological deficits were left.

CONCLUSION: Currently, endovascular embolization can be recommended as the top choice for the treatment of most true PCoA aneurysms, due to its advanced technique, especially the application of the stent-assisted coiling technique, combined with its advantage of mininal invasiveness and quick recovery. However, the choice of treatment methods should be based on the clinical and anatomical characteristics of the aneurysm and the skillfulness of the surgeon.
\end{abstract}

KEYWORDS: Angiography, Endovascular treatment, Aneurysm

ÖZ

AMAÇ: Gerçek posterior komünikan arter (PCOA) anevrizmaları nadirdir ama çok önemlidir. Endovasküler embolizasyonla tedavi edilmiş olan bu ölümcül hastalığın bulunduğu 9 hastayı gözden geçiriyor ve gerçek PCoA anevrizmalarının tedavisinde endovasküler embolizasyonun önemini tartışıyoruz.

YÖNTEM ve GEREÇLER: Eylül 2006 ile Mayıs 2012 arasında, dijital substraksiyon anjiyografi (DSA) ile doğrulanmış gerçek PCoA anevrizmaları olan 9 hasta endovasküler embolizasyon ile tedavi edildi. Hastalar minimum 17 ay takip edildi ve Glasgow Sonuç Ölçeği (GOS) puanıyla değerlendirildi.

BULGULAR: Tüm hastalar rüptüre anevrizmalardan spontan subaraknoid kanamayla geldi. Erkeklerin kadınlara oranı 1:2 şeklindeydi ve ortalama başlangıç yaşı 59,9 (52-72) yıldı. Preoperatif Hunt-Hess ölçeği puanları I ila III şeklindeydi. Tüm hastalar tatminkar şekilde iyileşmişti. Herhangi bir kalıcı nörolojik defisit yoktu.

SONUÇ: Şu anda endovasküler embolizasyon, gelişmiş tekniği ve özellikle stent yardımlı sarmal tekniğinin uygulanması ve minimal invazivlik ve hızlı iyileşmeyle kombine avantajı sayesinde çoğu gerçek PCoA anevrizmasının tedavisinde en iyi tercih olarak önerilebilir. Ancak tedavi yöntemleri seçimi anevrizmanın klinik ve anatomik özellikleri ve cerrahın becerileri temelinde yapılmalıdır.

ANAHTAR SÖZCÜKLER: Anjiyografi, Endovasküler tedavi, Anevrizma

\section{INTRODUCTION}

The posterior communicating artery $(\mathrm{PCOA})$, which is the connection between the internal carotid artery and the posterior cerebral artery, is a part of the Willis circle. Traditionally, posterior communicating artery aneurysms are a group of aneurysms that include lesions at the junction of internal carotid artery (ICA) and PCoA, true aneurysms of the PCoA, and lesions of the junction of the PCoA and the posterior cerebral artery $(1,9,10,12)$. Strictly, PCoA aneurysms are those that originate from the PCoA itself (16), which is some distance away from its junction with ICA or posterior cerebral artery. Some literatures suggest that these aneurysms account for $0.1 \%-2.8 \%$ of all aneurysms and approximately $4.6 \%-13 \%$ of all PCoA aneurysms $(7,10$, 
$13,14,15)$. However, the precise incidence of true posterior communicating artery aneurysms remains unclear and is underestimated, because some patients die immediately after severe subarachnoid hemorrhage (SAH). These patients are not included in the statistical analysis. In addition, some patients are misdiagnosed. The posterior communicating artery gives birth to many important branches supplying the optic chiasm, oculomotor nerves, ventral thalamus, mammillary body, tuber cinereum, hypothalamus, and internal capsule. The true PCOA aneurysms can have a space-occupying effect and rupture, causing damage to the surrounding tissues and thus endangering the life of the patient, and proper treatment is therefore necessary $(8,11)$. Microsurgery and endovascular treatment can be chosen. The present study described the endovascular treatment of 9 patients with ruptured true PCoA aneurysms.

\section{PATIENTS and METHODS}

From September 2006 to May 2012, nine patients with true PCoA aneurysms were admitted to People's Hospital of Rizhao. Clinical presentation, serial radiological imaging, diagnosis, management, and outcomes of these patients were analyzed.

All patients had computerized tomography (CT) scans and digital subtraction angiography (DSA). According to the patients' clinical condition and imaging results, we use endovascular treatment to treat the patients. Before operation, all patients must be given general anesthesia. They were examined by 3D-DSA angiography. A suitable working angle was chosen and this angle could reveal the internal carotid artery, posterior communicating artery and the body, neck and diameter of aneurysm well. The microcatheter tip was molded well and then the microcatheter was placed in the aneurysm. A proper spring coil was chosen to basket, occlusion, until aneurysm was not developing.

Post-surgical follow-up was evaluated by the Glasgow Outcome Scale (GOS) score. Clinical data and management results are listed in Table I.

\section{RESULTS}

\section{Clinical Finding}

Initial symptom of all patients was a sudden headache. One case exhibited gait instability. Four patients had a history of hypertension, but no patient had a history of head trauma. All patients suffered SAH. According to the Hunt and Hess grade, eight patients were I-II grade and one was III grade. The ratio of male and female patients with true PCoA aneurysms was $1: 2$, and the patients were between 52 and 72 years old (average age: 59.9).

\section{Radiological Findings}

Based on the results of the CT scans, all patients presented with SAH of a ruptured aneurysm. Five of the 9 lesions were located on the right side and four on the left side. The neck of the aneurysms ranged from 3 to $7 \mathrm{~mm}$ in length, and the aneurysm diameter ranged from 6 to $11 \mathrm{~mm}$ in length.
All patients had a fetal posterior cerebral artery. Seven aneurysms originated from the part, which was $2 \sim 3 \mathrm{~mm}$ away from the junction of the ICA. One aneurysm was located in the middle portion of the posterior communicating artery. One aneurysm was proximal to the posterior cerebral artery.

\section{Endovascular Treatment}

Seven aneurysms of our cases were completely embolized, and 2 cases were embolized about 95\%. Eight cases were treated solely by coil embolization (Figure 1A-C; 2A-D). One case was treated by stent-assisted coiling techniques.

\section{Clinical Outcomes}

Successful endovascular treatment was carried out in 9 patients and there were no complications or neurological deficits observed during or after treatment. Follow-up examinations revealed a GOS score of 5 in all patients. Stentassisted coiling was used in one patient with a wide-necked aneurysm.

\section{DISCUSSION}

Like other cerebral aneurysms, the definitive cause of the true PCoA aneurysms remains unknown. Some factors, such as hypertension, arteriosclerosis, intrinsic disorders of the vessel wall, contraceptive use, and trauma can predispose to true PCoA aneurysms. Several studies have reported that PCoA and anterior communicating artery aneurysms are more prone to rupture than aneurysms in other parts $(2,3,4,5)$. In the analysis of the available information from the included case reports and case series, 44 of 49 (89.8\%) "true" PCoA aneurysms were ruptured, demonstrating that true posterior communicating artery aneurysms are more prone to rupture $(6,14)$.

A good understanding of the location and configuration of the aneurysm neck is very important in the successful treatment of these lesions, so it is necessary to classify "true" PCoA aneurysms and make an accurate localizing diagnosis. According to the aneurysm location, true PCoA aneurysms can be divided into 3 parts: (1) aneurysm proximal to the posterior cerebral artery, which is $2 \sim 3 \mathrm{~mm}$ away from the junction of the ICA; (2) aneurysm located in the middle portion of the posterior communicating artery; (3) aneurysm distal to the junction of the ICA: aneurysms are proximal to the posterior cerebral artery. Seven aneurysms of our cases originated from the first part, one aneurysm originated from the second part, and one aneurysm originated from the last part.

Anatomical specificity of true PCoA aneurysms determines the special characteristics of the treatment. We found that the homopleural posterior cerebral artery of these aneurysms was almost fetal type. It is necessary to protect the patency of the posterior communicating artery. Otherwise, there will be disastrous consequences. According to the patient's clinical condition and imaging results, microsurgery or an endovascular approach can be chosen. The embolization technique has many individual characteristics based on the size of the aneurysms' neck. 
Table I: Details of 9 Patients who Suffered True Posterior Communicating Artery Aneurysms

\begin{tabular}{|c|c|c|c|c|c|c|c|c|c|}
\hline $\begin{array}{l}\text { Patient } \\
\text { no. }\end{array}$ & $\begin{array}{l}\text { Sex/age } \\
\text { (years) }\end{array}$ & Location & Presentation & $\mathbf{H}-\mathbf{H}$ & $\begin{array}{l}\text { Illrd nerve } \\
\text { Paralysis }\end{array}$ & Treatment & $\begin{array}{c}\text { Angiographic } \\
\text { outcome }\end{array}$ & $\begin{array}{l}\text { Follow-up } \\
\text { (months) }\end{array}$ & Gos \\
\hline 1 & $M / 52$ & $\mathrm{R} / \mathrm{PCoA}$ & SAH & I & + & endovascular treatment & Complete & 18 & 5 \\
\hline 2 & $F / 53$ & $\mathrm{~L} / \mathrm{PCoA}$ & $\mathrm{SAH}$ & II & + & endovascular treatment & Complete & 20 & 5 \\
\hline 3 & $\mathrm{~F} / 53$ & $\mathrm{R} / \mathrm{PCOA}$ & $\mathrm{SAH}$ & III & - & endovascular treatment & Complete & 19 & 5 \\
\hline 4 & $M / 59$ & $\mathrm{R} / \mathrm{PCOA}$ & $\mathrm{SAH}$ & II & - & endovascular treatment & Complete & 25 & 5 \\
\hline 5 & $M / 60$ & $\mathrm{~L} / \mathrm{PCoA}$ & SAH & I & - & endovascular treatment & Complete & 17 & 5 \\
\hline 6 & $F / 62$ & $\mathrm{~L} / \mathrm{PCOA}$ & SAH & I & + & endovascular treatment & $\begin{array}{c}\text { nearly } \\
\text { Complete }\end{array}$ & 22 & 5 \\
\hline 7 & $\mathrm{~F} / 63$ & $\mathrm{~L} / \mathrm{PCOA}$ & $\mathrm{SAH}$ & I & + & endovascular treatment & Complete & 23 & 5 \\
\hline 8 & $\mathrm{~F} / 65$ & $\mathrm{R} / \mathrm{PCOA}$ & $\mathrm{SAH}$ & ॥ & - & endovascular treatment & $\begin{array}{c}\text { nearly } \\
\text { Complete }\end{array}$ & 26 & 5 \\
\hline 9 & $\mathrm{~F} / 72$ & $\mathrm{~L} / \mathrm{PCoA}$ & SAH & 1 & - & endovascular treatment & Complete & 22 & 5 \\
\hline
\end{tabular}

$\mathbf{G O S}=$ Glasgow outcome scale score, $\boldsymbol{H}-\boldsymbol{H}=$ Hunt and Hess score, $\boldsymbol{R}=$ right, $\mathbf{L}=$ left, $\mathbf{P C O A}=$ posterior communicating artery, $\mathbf{S A H}=$ subarachnoid hemorrhage
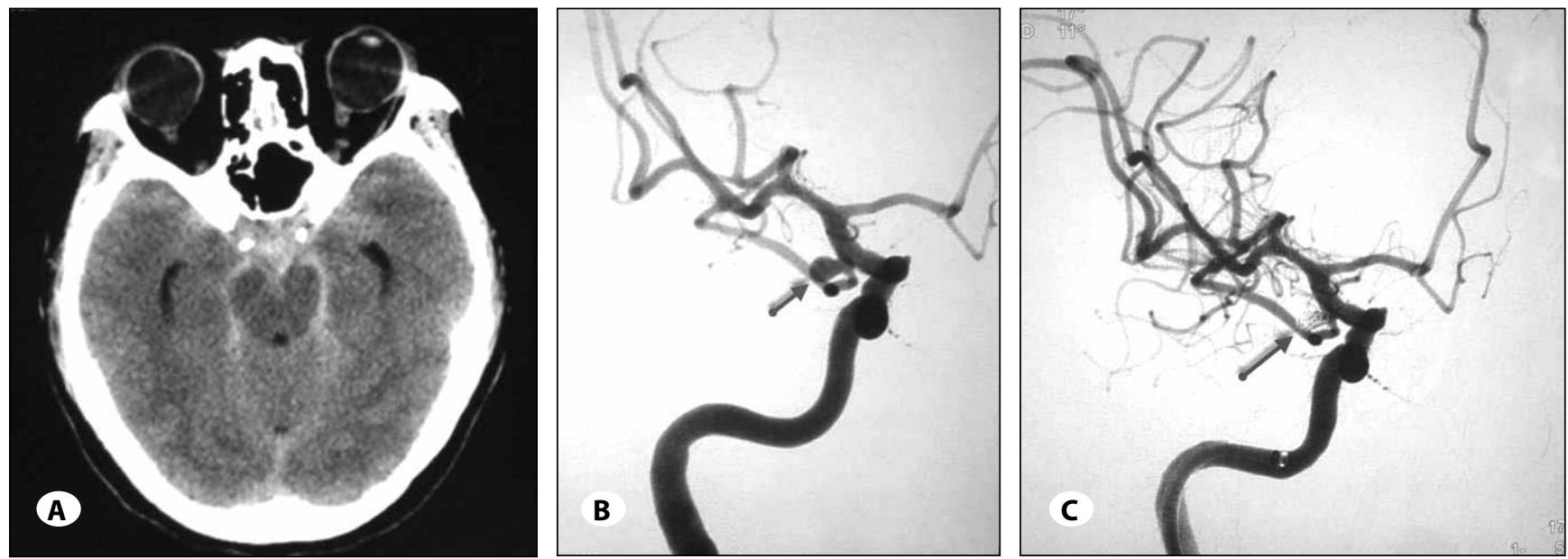

Figure 1: Patient 1. A) Axial CT scan showing a subarachnoid hemorrhage. B) (Oblique view) angiograms showing one true posterior communicating artery aneurysms. C) (Oblique view) showing the tip of the micro-catheter or micro-guidewire we made single curved and used six coils for the embolization.

Most narrow-necked aneurysms can be treated solely by coil embolization, with no need of dual-catheter technique or stent implantation. According to our experience, it was sufficient for the tip of the micro-catheter or micro-guidewire to be single curved. Before arriving the aneurysm, it must pass through the internal carotid artery-posterior communicating artery and thus the supporting point lied within the posterior communicating artery. Of course, there were a few cases in which complicated multi-curves were needed. Contrarily, during the procedure of conventional coil embolization of internal carotid-posterior communicating aneurysms, the tip of the micro-catheter or micro-guidewire often needs to be multi-curved into a complex shape, with few cases single curved. This time the micro-catheter or micro-guidewire passes through only the internal carotid artery before arriving at the aneurysms, so the supporting point in such cases is within the internal carotid artery.
The embolization of wide-necked aneurysm is more complex, and the adoption of operative strategies largely depended on the preference and skill level of the doctor. In our experience, the double catheter and/or stent-assisted coiling techniques were optional and mandatory for relative and absolute widenecked aneurysms respectively. It is difficult to choose an appropriate path of intervention for wide-necked aneurysms of the posterior communicating artery, as the patency of surrounding arteries might vary hugely. In our experience, the ipsilateral internal carotid arteries were in good condition in most patients, and the guidewire or catheter could pass smoothly through the internal carotid artery and posterior and arrive at the aneurysms. For cases in which it was difficult to pass the guidewire or catheter through the ipsilateral internal carotid arteries due to stenosis or atherosclerotic plaque, there are two alternative pathways. One is the vertebral-basilar-posterior cerebral artery pathway, and if 

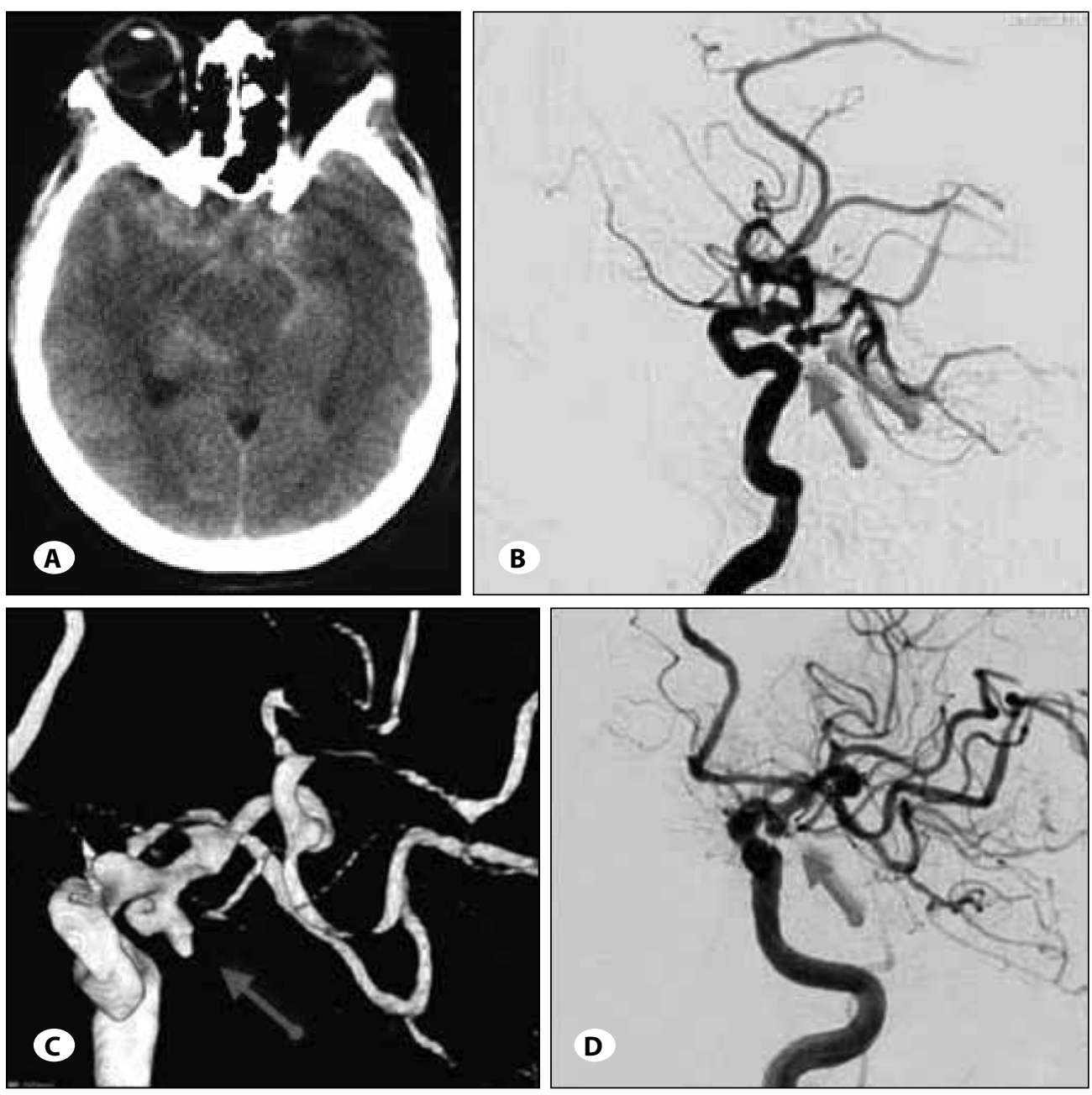

Figure 2: Patient 2. A) Axial CT scan showing a subarachnoid hemorrhage. B) (lateral view) angiograms showing that the big arrow was one true posterior communicating artery aneurysm (the little arrow was a vascular tortuosity); C) (3D-DSA) showing the relationship between true posterior communicating artery aneurysms and peripheral vessels. D) showing the tip of the micro-catheter or microguidewire we made multicurved and used four coils for the embolization. its patency permits, this path can lead to aneurysms of the posterior communicating artery, and even the ipsilateral internal carotid artery for stent implantation. The other is the contralateral internal carotid-anterior communicating artery pathway, used when the first pathway was hard to pass through. The stent can be sent to the aneurysm of the posterior communicating artery through the contralateral internal carotid-anterior communicating-ipsilateral internal carotid arteries. But, this path is often difficult to pass the guidewire or catheter to its destination, as there are so many curves. If the above methods are unworkable, microsurgery is a good choice.

\section{CONCLUSIONS}

Patients with ruptured true PCoA aneurysms should receive timely treatment because of the high risk of rebleeding and subsequent mortality. Currently, endovascular embolization can be recommended as the top choice for treatment of most truePCoAaneurysms, due to itsadvanced technique, especially the application of the stent-assisted coiling technique, combined with its advantage of minimal invasiveness and quick recovery. However, the choice of treatment methods should be based on the clinical and anatomical characteristics of the aneurysm and the skillfulness of the surgeon.

\section{REFERENCES}

1. Akimura $\mathrm{T}$, Abiko $\mathrm{S}$, Ito $\mathrm{H}$ : True posterior communicating artery aneurysm. Acta Neurol Scand 84:207-209, 1991

2. Asari S, Ohmoto T: Natural history and risk factors of unruptured cerebral aneurysms. Clin Neurol Neurosurg 95:205-214, 1993

3. Carter BS, Sheth S, Chang E, Sethl M, Ogilvy CS:Epidemiology of the size distribution of intracranial bifurcation aneurysms: Smaller size of distal aneurysms and increasing size of unruptured aneurysms with age. Neurosurgery 58:217-223, 2006

4. Forget TR Jr, Benitez R, Veznedaroglu E, Sharan A, Mitchell W, Silva $M$, Rosenwasser RH: A review of size and location of ruptured intracranial aneurysms. Neurosurgery 49:13221325,2001

5. Hademenos GJ, Massoud TF, Turjman F, Sayre JW: Anatomical and morphological factors correlating with rupture of intracranial aneurysms in patients referred for endovascular treatment. Neuroradiology 40:755-760, 1998 
6. He W, Gandhi CD, Quinn J, Karimi R, Prestigiacomo CJ: True aneurysms of the posterior communicating artery: A systematic review and meta-analysis of individual patient data. World Neurosurg 75(1):64-72,2011

7. He W, Hauptman J, Pasupuleti L, Setton A, Farrow MG, Kasper L, Karimi R, Gandhi CD, Catrambone JE, Prestigiacomo CJ:True posterior communicating artery aneurysms: Are they more prone to rupture? A biomorphometric analysis. J Neurosurg 112:611-615, 2010

8. Horiuchi T, Nakagawa F, Tanaka Y, Miyama H, Hongo K: Anterior subtemporal approach for posteriorly projecting posterior communicating artery aneurysms. Neurosurg Rev 30:203-207, 2007

9. Kudo $\mathrm{T}$ : An operative complication in a patient with a true posterior communicating artery aneurysm: Case report and review of the literature. Neurosurgery 27:650-653, 1990

10. Muneda K, Yoshizu H, Terada H:True posterior communicating artery aneurysm. No ShinkeiGeka 29:163-168, 2001
11. Nakao Y, WatanabeM, Yamamoto T, MoriK, Maeda M: Dissecting aneurysmof the posterior communicating artery. Acta Neurochir (Wien) 146:1365-1367, 2004

12. Peerless SJ: The surgical approach to middle cerebral and posterior communicating aneurysms. Clin Neurosurg 21: 151-165, 1974

13. Prestigiacomo CJ, Setton A, Niimi Y, Pryor J, Wong J, Flamm ES, Langer D, Berenstein A: Recognition andimaging of "true" posterior communicating artery aneurysms. CNS Annual Meeting Abstract, 2001

14. Timothy J, SharrM, Doshi B: Perils of a 'true' posterior communicating artery aneurysm. Br J Neurosurg 9:789-791, 1995

15. Yasargil MG, Smith RD: Management of aneurysms of anterior circulation by intracranial procedures. In Youmans JR (ed), Neurological Surgery, vol. 2, 2nd ed. Philadelphia: Saunders, 1982:1663-1696

16. Yoshida M, Watanabe $M$, Kuramoto S: "True" posterior communicating artery aneurysm. Surg Neurol 11:379-381, 1979 